\title{
Sustainable Tourism Development on Water Front Tourism and Hospitality Practices at the Tourist Destination Site: The Case of Bahirdar City, Ethiopia.
}

\author{
Dr. Balew Baye ${ }^{1 *}$, Dagnachew Nega ${ }^{2}$ \\ ${ }^{I}$ Assistant professor in culture and history Administration Vice President of Debre Tabor University \\ ${ }^{2}$ Head of Tourism and Hotel Management Department Debre Tabor University
}

*Corresponding Author: Dr. Balew Baye, Assistant professor in culture and history Administration Vice President of Debre Tabor University

\begin{abstract}
Waterfront tourism development is now becoming one of the fashion practices which are held at the water front areas. Bahirdar is one of the best places to ensure of waterfront development. The main objective of the study is to assess the negative impacts of waterfront activities for sustainable tourism development, to assess the tourist attractions around the water front, to indicate solutions through identifying the key stakeholders. Descriptive research design was employed. The research approach was qualitative. Findings revealed that Lack of awareness about the ecotourism concepts, negative impacts of tourism on the waterfront bodies, lack of sufficient GIS application professionals, lack of the long term plan developed for the waterfront area, environmental impact assessment is not developed, lack of developing environmental auditing. Tourism and hospitality stake holders should take actions on different activities of water front practices.
\end{abstract}

Keywords: Bahirdar, waterfront tourism, sustainable tourism development, Lake Tana.

\section{INTRODUCTION}

Water is needed in all aspects of life. Water obtained from rivers, lakes, springs and wells has been used for drinking, washing, agriculture, and manufacturing. Most of the Earth's liquid fresh water is found, not in lakes and rivers, but is stored underground in aquifers. Tourism plays a significant role in the redevelopment of urban waterfronts. (Nguyen, 2010) Stated, there is no doubt that recreation and tourism can be used as catalysts for waterfront redevelopment. Many cities have developed from, and are located near, the waterside. The four ancient civilizations originated at riversides, because of the convenient water supply for drinking and irrigation, transport, and many other benefits. Around a third to half of the world's population lives near coastal areas. Even land, people prefer to live near streams, rivers, lakes or other water resources (Satyanaryana and Behailu, 2015).

In most cases, the main drivers of waterfront developments are to improve public access; to improve the image of the city; to achieve economic regeneration; to provide facilities and services for local people; and to underpin the improvement of the physical environment. In some cases, the underlying forces that shape waterfront revitalization are the economic and political intentions of planners and developers (Stella, 2013).The redevelopment of waterfronts is not a straightforward process. It must be integrated into a long-term plan that incorporates all players involved in the waterfronts planning for the redevelopment of waterfront areas requires creative solutions of urban land-use planning. (Craig-Smith, 1995) suggested that land-use continuity may be achieved by linking waterfront development with inland uses.

All waterside redevelopments, it seems, have some common challenges. The mixed-use approach, promoting the unique characteristics of each community, has been shown to be one of the most successful means of enhancing and maintaining waterfront areas, especially those in urban centers. Government plays a critical role in the redevelopment of urban waterfronts in several respects. It plays a key role in attracting private and public investment. Through its planning and adoption of regulations and inducements it can establish a development theme for the waterfront, which sets the scale, quality, and sequence of redevelopment (Craig-Smith, 1995). 
Urban waterfronts, generally referred as the part of a town or city that abuts water, especially a district of wharves where ships dock, have always been places full of location advantages, due to the concentration of interactive land and water activities. Water, as a primary human resource for nourishment, irrigation, and transportation, was the raison d'être for man's earliest settlements and hence, a vital part of civilization involves events and development that have occurred along the world's coasts, rivers, bays, and lakes. Historically, port development has dominated local communities, bringing economic well-being and a cosmopolitan dimension to urban life. Ports became significant settlements based on a range of productive sectors, both within manufacturing and today's - product servicesll, and also through the growth of a prosperous urbanist culture and society. From the early fishing village, developing from a settlement close to water, to the busy transshipment stations serving the rapidly growing world transportation, up to the modern expanding logistics hubs, this development process of value-added labor, value-added production, and value-added service epitomizes the diversity of ports and their significance to life, industry, and commerce (Stella,2013).

Tourism is the largest business sector of the world economy accounting for $10 \%$ of global GDP, one in twelve jobs globally and 35\% of the world export services since 1985; tourism has been growing an average of 9\%per year (Jantirar,2012). The impact of tourism industries are not only limited with creating job opportunity. Most people think of tourism in terms of economic impacts, jobs, and taxes. However, the range of impacts from tourism is broad and often influences areas beyond those commonly associated with tourism. Depending on the availability of the resources the impact of tourism varies from place to place. The economic impact of tourism industry of one country may not be an impact for the other in which the economic aspects of the specified country may not mainly depend on the tourism industry. The social service, community attitude, tax etc are the other important products of tourism industry. As mentioned earlier the impacts of those products on different countries vary with respect to the role of the tourism industry based on the availability of the natural resources (Jantirar, 2012).

Ethiopia has numerous water-based tourist attractions. Major among these are the rift valley lakes, the Tis Isat and other waterfalls. Lakes Langano, Abijata and Shalla, Lake Tana, Lake Awassa, Zeway and Chamo. The Tis Isat falls, the hot springs of Sodere and Wondo Genet are also among the other tourist attractions currently being used [ibid].Ethiopia is known as the water tower of North East Africa. Surface water resources in Ethiopia flow in 12 major river basins. It is estimated that an average of 122.19 billion $\mathrm{m} 3$ of water is annually discharged from these basins. The country's total ground water resources are estimated to be around 2.6 billion m3. Much of the discharge of Ethiopia's rivers flows into neighboring countries. The amount that remains in the country is not more than 9 percent (Satyanaryana and Behailu, 2015).

Amhara region is one of the richest states in tourism resources in Ethiopia. Among the UNESCO Previously registered eighth wonders of the world tourist destination areas of Ethiopia; three of them are found in Amhara region. Lalibela, the walls of Fassil palace, Northern Mountain inhabit the Chilada Baboon, Lake Tana monasteries and Tis Abay falls located around Bahirdar are the main tourist destination areas in the region. Bahirdar city waterfront area is one of the most tourism potentials which is based the largest lake of the county, Lake Tana. There are a lot of use and benefits of the waterfront for investment, job opportunity in the case of tourism development in the city. The waterfront is the base for the development of Bahirdar. It drew the intentions of a lot of domestic and foreign tourists. In front of the waterfront are many island monasteries which still used as the main tourist attraction sites. Bahirdar Water front Tourism can be organized into four sections like Boating, Sport or Extreme Sport Adventure, Sustainability.

Bahirdar is one of the tourist destination urban centers in the country and the region as well. The existence of tourist attraction sites such as Lake Tana and the monasteries in its islands, Abay River and the Tis Abay falls can be mentioned as a reason for the increment of tourists from time to time. The city's proximity to walls of Fasiledas palace in Gondar and rock hewn churches of Lalibela also reinforces the growth of tourism in Bahirdar. The expansions of hotels, physical infrastructure and other service sectors in the city were taken as the main reasons for the increment of tourists according to the information collected in Bahirdar tourism office. However, the use of water front development is still in the infant stage. Using Technological advancement like GIS is used to locate each products of the waterfront area in the appropriate location and it tends to minimize many of the problems and impacts of the area. 


\subsection{Statement of the Problem}

Ethiopia is the water tower of Africa. The country is rich and endowed with a lots of water resources like rivers, lakes, streams, valley waterfalls. All these are found throughout the country. Among these, Bahirdar is one of the nature gifted city which is surrounded with Lake Tana, the highest in the country and Blue Nile River the longest in the world. Bahirdar, having theses the top most waterfront tourism resource, is now the most appropriate place for water front tourism development. However though the city is gifted with such resources in the water front tourism, the development resources using GIS application is still found on the infant stage with many of the gaps on the environmental, socio-cultural and economical aspects. Since GIS application is one of the basic instruments for the development of waterfront tourism development and makes most of the task easy and accessible with cost effective of capital and labor, the use and the potentials of using different application is not assessed and ensured with the concerned bodies. Thus taking this issue in to account, researcher stood to assess the level of waterfront tourism development in Bahirdar which is not yet well touched such area which is a must to develop it sustainably.

\subsection{Objective of the Study}

- To examine the issues of waterfront tourism related activities for sustainable tourism development.

- To investigate the relevant measures and mechanisms to be taken for Bahirdar waterfront tourism development

- To explore waterfront tourism potentials for sustainable tourism development at the city of Bahirdar

\section{RESEARCH METHODS AND MATERIALS}

\subsection{Study Area}

Bahirdar is situated on the southern shore of Lake Tana, the source of the Blue Nile (or Abay), in what was previously the Gojjam province. The city is located approximately $578 \mathrm{~km}$ north-northwest of Addis Ababa, having a latitude and longitude of $11^{\circ} 36^{\prime} \mathrm{N} 37^{\circ} 23^{\prime} \mathrm{ECoordinates:} 11^{\circ} 36^{\prime} \mathrm{N} 37^{\circ} 23^{\prime} \mathrm{E}$ and an elevation of about 1,800 meters (5,906 feet) above sea le (https://en.wikipedia .org/w/index.php?title=Bahir_Dar\&oldid=768793133).Lake is the source of the Blue Nile and is the largest lake in Ethiopia. Located in Amhara Region in the north-western Ethiopian Highlands, the lake is approximately 84 kilometers long and 66 kilometers wide, with a maximum depth of 15 meters and an elevation of 1,788 meters. Lake Tana is fed by the Lesser Abay, Reb and Gumara rivers. Its surface area ranges from 3,000 to 3,500 km, depending on season and rainfall. The lake level has been regulated since the construction of the control weir where the lake discharges into the Blue Nile. This controls the flow to the Blue Nile Falls (Tis Abay) and hydro-power station (https://en.wikipedia. org/w/index.php?title=Lake_Tana\&oldid=767522855).

\subsection{Research Design}

Descriptive research was employed. Since the main aim is to identify and describe the current features and use of the waterfront tourism resources of Bahirdar city. In this research method, issues for waterfront tourism development were evaluated, evaluations of the current accommodation facilities on the water front are assessed, and the impacts of the Lake Tana water front area are identified. So to assess all this features, descriptive research method is the appropriate one. The qualitative research approach was employed. The advantages of qualitative methodology have been widely acknowledged by scholars. According to Creswell, qualitative methodology refers to the strategies of researchers to pursue knowledge and the general approach to the study of research topics, rather than the specific methods that they actually use. The cornerstone of qualitative methodology is the description of people, places and events (Creswell, 2003). 


\title{
2.3. Data Collection Procedures
}

The populations of the study were the tourists, tourist guide association, tour and travel operators and local communities. The researcher took 42 respondents from domestic tourists, foreign tourists, local communities, tourism experts, tourist guides, and business owners. Purposively sampling method was fully considered. The main reason for selecting such types of sampling method enabled the researcher to pick his appropriate respondents for the purpose finding the outshine outcome based on the objectives accordingly. Primary and secondary data were used to collect for conducting this study .The data were collected from domestic and foreign tourists, local communities, experts, leaders of the governmental organizations through in-depth interview. The other instrument is also conducted with observation. Filed observation was taken as one of the data collecting instrument. The interview and observation instrument was held on the suit, since there are a lot of domestic and foreign tourist can easily found near the waterfront area. Mostly this was conducted after they explore their visiting the destination to get the relevant data for the study. After the data collection process, the most essential stage was data analysis process so the data were analyzed using different methods like through triangulation with content analysis (Silverman, 2006).

\section{DATA ANALYSIS AND INTERPRETATION}

\subsection{Issues of Water Front Tourism Development}

\subsubsection{No Buffer and Core Zone}

For every tourism resources, there should be at least two zones. Observation clearly proved that Lake Tana has not its own core zone and buffer zone. The main problem of waterfront tourism development in at the city of Bahirdar is missing such zone. If there were core zone and buffer zone, there could be free space for between Lake Body and the human contact.

One of the tourists answer the following regarding the buffer zone:

Natural attractions should be a little far from nay human contact, unless there will be conflict between man with nature. Man should be a power for the nature rather than being an enemy. Most of the world's natures have been lost due to human activities.

\subsubsection{Litter and Visual Pollution}

As the triangulated interview showed that water front area of Bahirdar is highly affected with tourism. It is known that tourism has a lot of negative impacts on waterfront as the waterfront is one of the components of environmental aspects.

One of the interviewee, from the domestic tourist said,

\begin{abstract}
In Bahirdar waterfront area, there is a highly negative impact which derived from tourism activities. For instance pollution is one of the most seen which can be seen as the negative impacts of the area. Fuel disposal, litter, smoke are some of parts of pollution seen in Bahirdar waterfront area. Waterfront area is the fragile part of the environment which is sensitive unless used properly. Still water consumption is another negative impact of tourism on the waterfront area. Because there are accommodation facilities hotels which are found in the waterfront area, so they use high amount of water.
\end{abstract}

So as depicted from the above interviewee, specifically in Bahirdar waterfront area, tourism negative impacts like pollution should be considered.

Based on the observation taken through researcher, in addition to pollution and water consumptions, litter are still the negative impacts of tourism which severely affect the potentials. As observed, due to tourism, some accommodation facilities put their negative impacts on the waterfront development due lack of GIS application support at the very beginning. For instance as observation assured that there are very large buildings including different accommodation facilities whose location is not compatible with the impacts of tourism activities on the sustainable tourism development of the destination. The highest buildings can prevent any far view of the Lake Tana. In addition to this, their draining system is may directly contact with water which can damage the ecosystem diversity of the destination. 


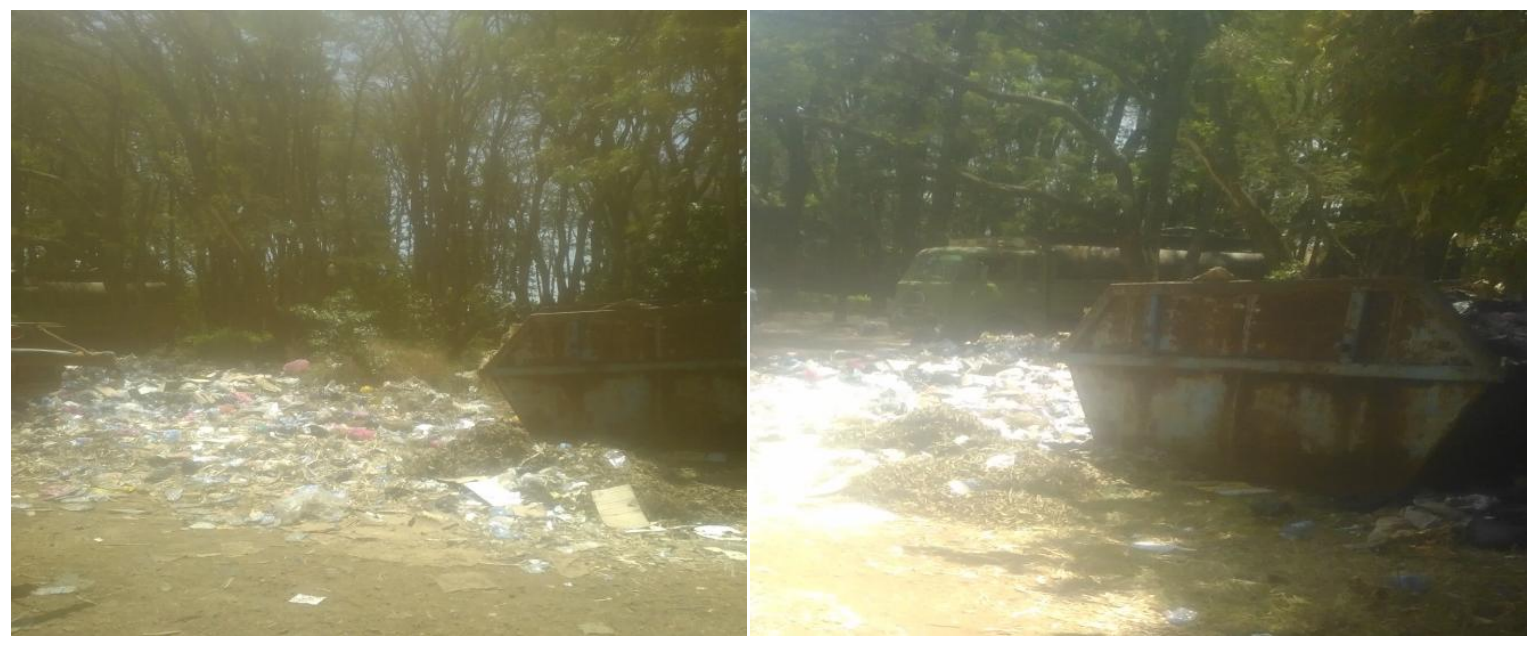

Figure1. Pollution nearby Lake Tana

Source: Researcher's own, 2020

\subsubsection{Wrong Investment Location on the Lake}

After categorizing the response of the respondent, the researcher triangulated their response accordingly. Thus, for the sake of the sustainability of the water front development area of Bahirdar city in the case the dimensions of environmental, social and economic, most of the accommodation facilities are not properly built. Most of the tourist facilities' are built very near on the lake. This actually may give a great pleasure for the tourists. However in the view of sustainability, such types of the facilities will easily make the area fragile. As observed, there is no free space between the accommodation facilities and the lake. So that in between the tourist can have free space for relaxation and also at the time when there can be summer even if the level of water may rise, may resource will be free from the damage.

One of the foreign tourists stated the following

I don't know why most of the hotel facilities are built in such a way. There is a great mistake! Before this, there should be environmental impact assessment. If that was done, attractive beaches can be seen here. Now these facilities are exposed easily for natural problems like when the level of sea rise, great wave and the like.

In general as depicted from the above interviewee, it showed that to locate the facilities at their appropriate location, it is better to use even the modern technology application. Since this makes things easy.

So the main reason for missing this is identified as lack of awareness about the ecotourism concepts, impacts of tourism on the waterfront bodies, lack of the real GIS application professionals, lack of the long term plan developed for the waterfront area, environmental impact assessment is not developed, lack of developing environmental auditing

\subsection{Mechanisms for the Development of Waterfront Tourism Development}

\subsubsection{Use GIS Application Properly}

The measures to be considered are still discussed as well. Today nothing is done without GIS applications. Especially the using of GIS applications for tourism purpose is becoming growth from time to time. However unless there is measures/solutions for the problem occurred on Bahirdar waterfront with help of GIS application, still it is difficult to use the resource effectively and efficiently.

As triangulated form respondents, GIS application is a recent technological output. The first use of GIS application was for attacking, war and controlling the competitors among those well developed nations. Now a day it is used also for the development and solving many problems of one's nation. Like that in Ethiopia, GIS application is now becoming started to make any subject matters simple. 
However is not still developed and familiar through professionals. It is limited to those geologists, geographers, researchers. But all the peoples should know its application.

One of the experts in hotel worker stated the following:

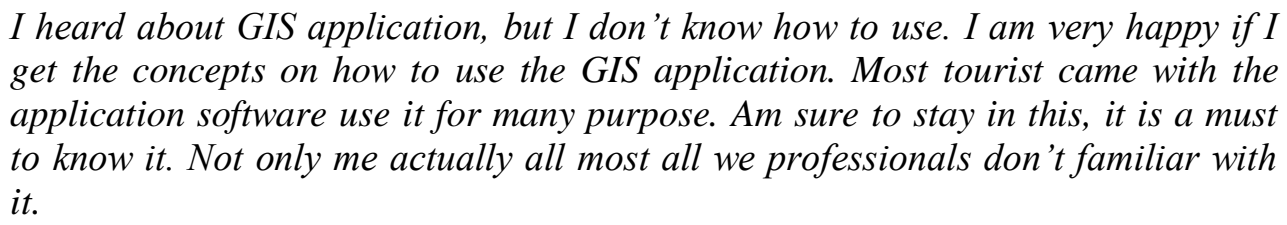

One of the experts of tour guiding association there gave brief suggestions of the solution to be considered

With no doubt, GIS application is the basic instruments to solve many of the problems of waterfront area development in Bahirdar city. Most importantly thanks to the application, even though it is not yet developed in this area, many things can be simplified. For instance everything including the facilities can be easily seen before the tourist come and visit the area. GIS can be used as a key tool to minimize accident hazard on roads, indicates the existing road network to be optimized and also the road safety measures to be improved. It makes the level of the local communities awareness increase. In addition to this responsible bodies should know the application of GIS to make their task on waterfront area fast and easy.

As depicted from the above response, to minimize the impacts of tourism on waterfront area, looking the application of GIS is a must. For instance the fragile area of waterfront environment is easily identified; the appropriate area for building of tourist facilities like hotel can be indicated.

\subsubsection{Capacity Building for Stakeholders and Local Community}

So it indicates awareness creation must be given for tourism experts, tour and travel operators, local guides associations, local peoples through media, conference, training, broacher trade fair and exhibition. The core reason for not being aware also discussed. As triangulated the response of respondents, the main reason for the lack of understanding well about the use of GIS application for the developments of Bahirdar waterfront area, lack of professional, high cost of technology, lack of concern. So that the government should give appropriate attention for the use of application since it is mandatory for the development of the local, regional and national economy, for safety and security of one nation, and being competitors with the developed nations and to ensure the peace and security with neighboring countries.

In general, training on both short term and long term program must be opened. Universities should set the curriculum and open the program and collaborate with different stakeholders and provide training as a community based tourism.

\subsubsection{Providing and Using Latest Tourist Map}

It is the very crucial to get every facilities easily and fast. As observed form the tourist information center of Bahirdar city, most of the existing maps are outdated. There is no map which is manipulated thought the latest GIS application. If there is such instrument, everybody can easily get what he/she wants without asking person. However there is no such developed map in the tourist information center.

\subsection{Potentials for Waterfront Tourism Development}

According to the observation and document analysis, there are many attraction sites near around the waterfront area. Monasteries are the most famous attraction sites described as follows.

\subsection{Accommodation Facilities Nearby The Lake}

Around the city of Bahir Dar, there are famous and quality accommodation facilities. These accommodation establishments are providing service for domestic and foreign tourists. 
Sustainable Tourism Development on Water Front Tourism and Hospitality Practices at the Tourist Destination Site: The Case of Bahirdar City, Ethiopia.

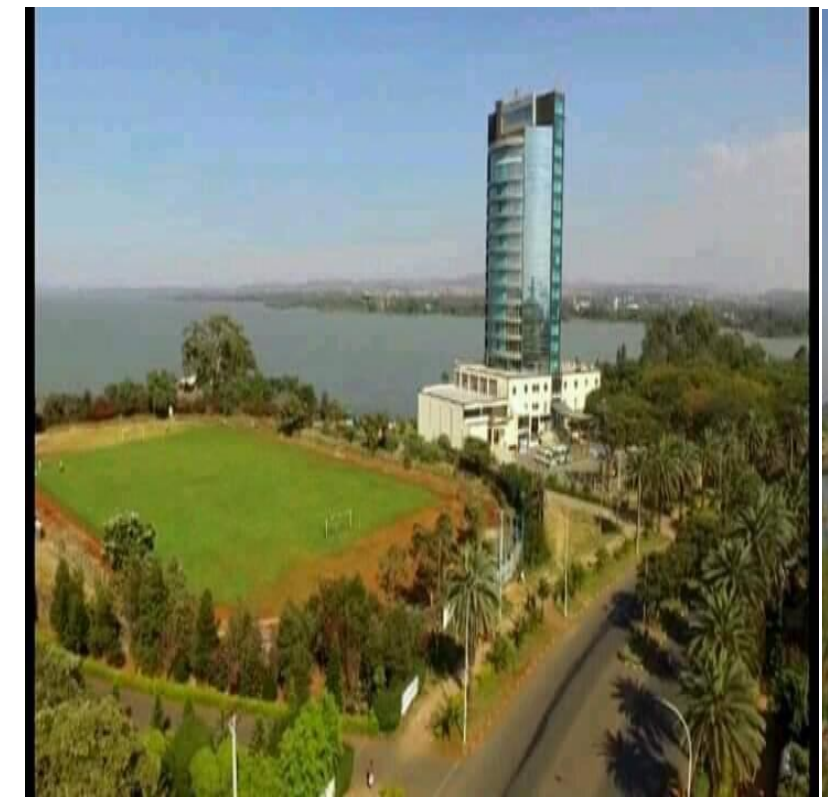

Figure2. Grand resort and Spa

Source: Hotel's website, 2020

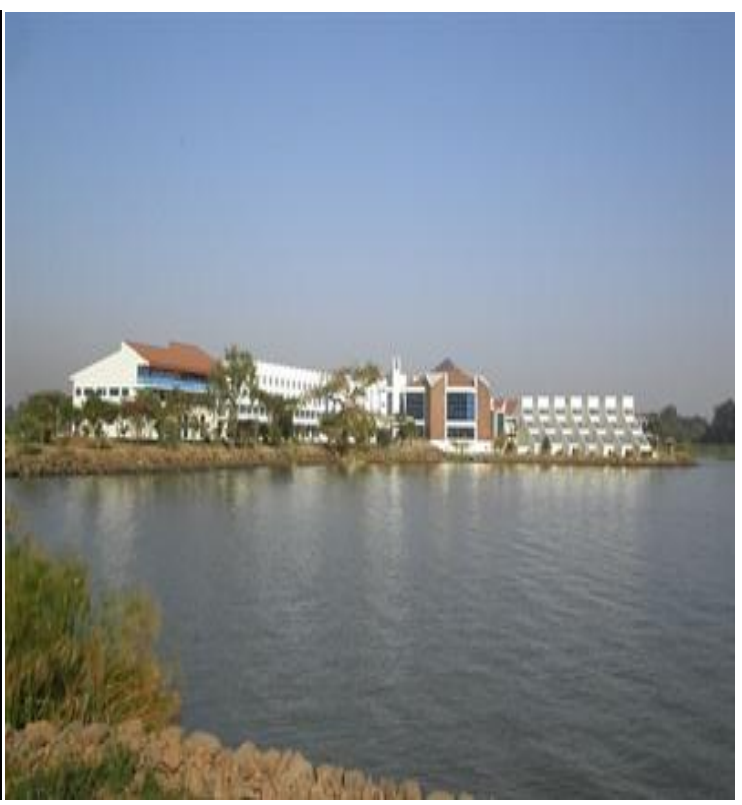

Figure3. Blue Nile Resort

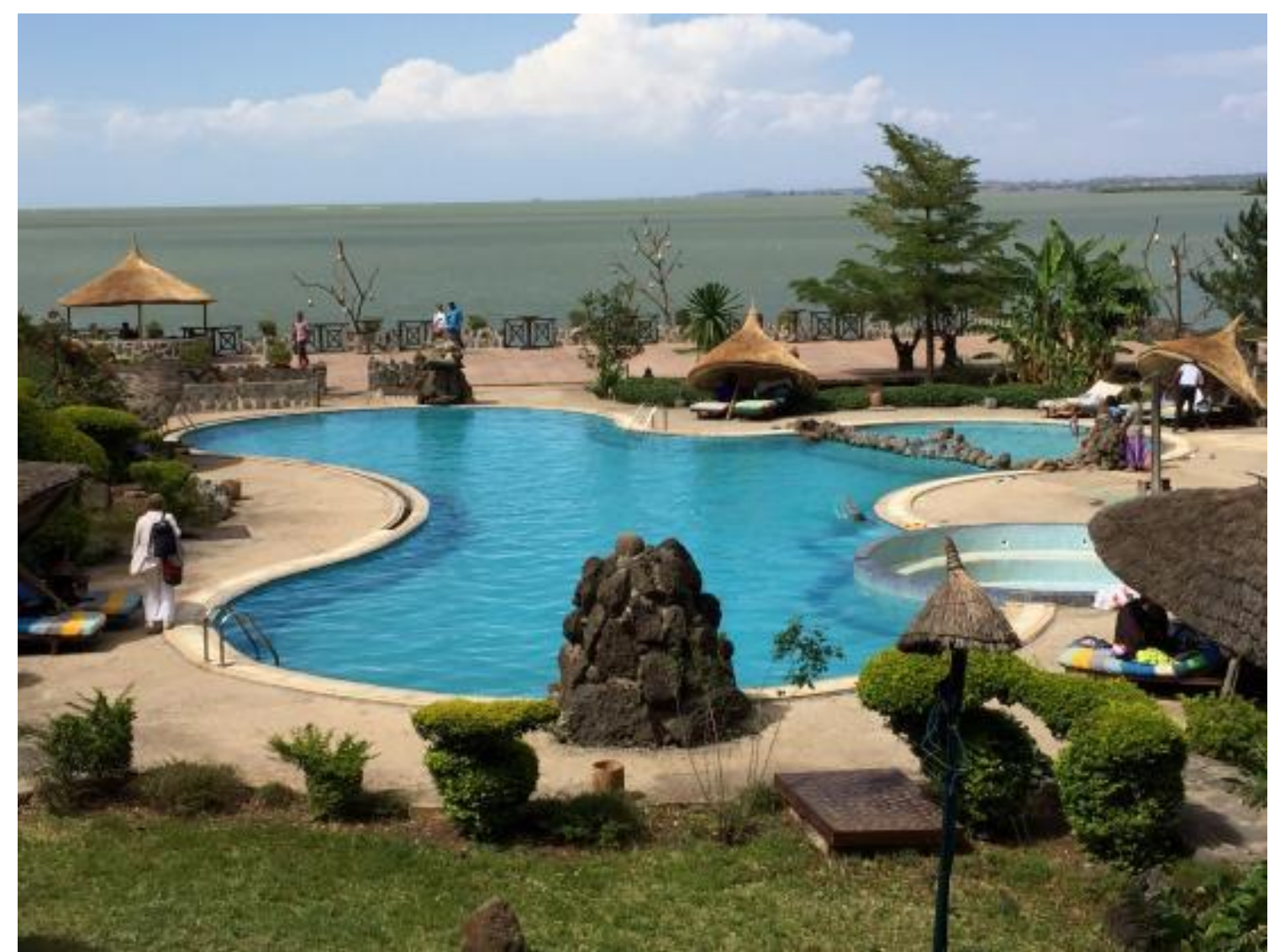

Figure4. Kuriftu Resort and spa at Bahir Dar

Source: Hotel's website, 2020

\section{Debre MARYAM MONASTERY}

The monastery of Debre Maryam is one of the newer monasteries of Lake Tana, having been built by Emperor Tewodros since the 19th century. A friendly priest welcomes all visitors and is happy to show you the ancient manuscripts stored there. It can be accessed by boat and a short walk through coffee, mango and fig trees that line the path. More adventurous travelers can rent a Tankwa papyrus boat from locals, 20 minutes on the road towards Gondar, just before the Nile Bridge. 


\subsection{Dega Estefanos Monastery}

Set on a hill around $100 \mathrm{~m}$ above the lake, a short trek up a winding path brings you to one of the most sacred monasteries, the monastery of Dega Estefanos. This monastery is of real historic interest, housing brightly colored ceremonial robes, a 16th century painting of the Madonna and the mummified remains of five Ethiopian emperors, displayed for visitors to view in modern, glass-sided coffins.

\subsection{Narga Selassie Monastery}

Narga Selassie, which means 'Trinity of the Rest', was built on Dek Island, the largest island of Lake Tana in the late 18th century. The church is one of the most peaceful and atmospheric on Lake Tana and is set in an extremely beautiful location.

\subsection{Kburan Gabriel Monastery}

Sadly, although it is said to be one of the most beautiful and atmospheric of the monasteries of Lake Tana, Kburan Gabriel is no longer open to the public. It was founded in the 14th century and rebuilt in the 17 th century. It is located the closest to Bahirdar. The round roof is supported by twelve pillars made from carved stones symbolizing the twelve apostles.

\subsection{Monasteries on the Zege Peninsula}

The rich forests on the Zege Peninsula are home to many medieval churches waiting for you to visit. The peninsula can easily be reached by boat or bicycle from Bahirdar. There are lots of water front tourism activities held at this site.

\subsection{Ura Kidane Mihret Monastery}

Is has been said that the inside of the Ura Kidane Mehret monastery is the most impressive and beautiful in the whole region. Just a 25 minute walk from the boat landing point will take you to the monastery, winding through coffee plantations under tall shady trees. The monastery is highly decorated with beautifully painted, colorful and vibrant frescoes depicting Ethiopian saints and the history of the Ethiopian-Orthodox Church. Both men and women are permitted to enter and there is also a small museum, the Zeghie Museum, for visitors to learn about hand-crafted objects and musical instruments that are still used be the local communities today.

\subsection{Bete Maryam Monastery}

A short walk on a path through coffee and lemon trees leads you to the oldest monastery on the peninsula, the Bete Maryam monastery. Attractive murals are sheltered behind stone columns here. These are also other tourist attraction sites nearby Bahirdar waterfront area. Most of these attraction sites are managed traditionally without the use of any technological advancement. Their location is not appropriately located and used. By using GIS application, many of the present and future risk of the attraction can easily identify. Many of the resource can be saved. It can be still the source of income.

\section{CONCLUSION}

It is known that water front tourism practice is a crucial issue which should be used properly for the sustainable development of water front tourism and enhance the beneficiary of the local communities. Due to not giving the appropriate attention for the use and benefits the issues for the variety of activities in regard with water front tourism development in Bahirdar, a lot of problems and risk happened. In Bahirdar water front tourism activities, evaluating the waterfront development with the help of GIS application is a must to be considered, there are a lots of problems on waterfront development like missing the buffer zone and core zone., litter and pollution and other negative impacts on water front area in Bahirdar city through wastage disposal, fuel, consumption of high amount of water for accommodation purpose, damage of flora and fauna.

As the study shows, the level of waterfront tourism development is very slow. So to afford such critical issues, applying the measurement is mandatory. It can have a great power to alleviate such 
impacts through locating the tourism products be it accommodations, attraction and transportation on the right place on an easy way. Application of GIS on such area is also open the opportunity for the water transportation modes like boat and others to be organized the water park entertainment like scuba diving, sport fishing and big game fishing, motorized water sports, such as jet skiing, wakeboarding, personal hydrofoils, and parasailing. As a result, the Bahirdar water front tourism development will be furnished fully. And finally it will enable to ensure the beneficiary of the local community which is one of the most concerns of sustainable development of tourism at the water front area.

\section{Recommendations}

- The key actors should get continuous and relevant training upon the latest technology application for water front tourism development in Bahirdar.

- The government should provide plan for short term and long term human resource capacity building to employ the right man at the right place.

- To develop the water front tourism in the city of Bahirdar, the negative impacts that affect the water front tourism should be identified and reduced.

- Since water front tourism is not developed well in the city of Bahirdar, continues efforts should be conducted through the right professionals of the field.

- The local people should involve and actively participate for the waterfront tourism development of the city.

- The stakeholders of the tourism industry should be involved during every process of GIS application on water front tourism development.

- The government, the host communities and the private tourism supplier should work cooperatively for the enhancements of water front tourism development.

- The government should open good opportunities to attract the local investors on the water tourism development.

- All the key actors of tourism industry should get awareness and get training on how to manipulate different waterfront tourism investments on different tourism activities like on tour route planning, on tourist site planning, on tourist site mapping and the like.

- The government should allocate sufficient budget to run different activities for the sustainable development of water front tourism development.

\section{REFERENCES}

[1] Craig-Smith, S. (1995). The Importance and Problems of City Waterside Regions. In S.

[2] Craig Smith and M. Fagence (Eds). Recreation and Tourism as a Catalyst for Urban

[3] Creswell, J. (2003). Research Design: qualitative, quantitative and mixed methods approaches.(2nd ed). Retrieved from www. Isites.harvard.edu.

[4] Douglass, R.W. (1982). Forest recreation. (3rd ed.). New York: Pergamon Press.

[5] Jantirar Abay. (2012), Land Allocation and the Publicness of Lake Tana Area in Bahir Dar

[6] City Ethiopian institute of Architecture, Building Construction and City Development, Addis Ababa University Addis Ababa

[7] Malone, P (1996). Introduction. In P. Malone (Ed.), City, Capital and Water (pp.1-14). London

[8] Nguyen Thi Hong Hanh, (2010): the wellington waterfront and tourism development: planning process and legislative framework, Victoria University of Wellington Problem and options for management.

[9] Samson Debele, 2010. Sustainable City Fabric for Urban Slum Areas, Case of Bahir Dar

[10] Satyanaryana \& Behailu, (2015): Water Front Tourism Development in Ethiopia: A GIS Approach. The Case of Gorgora Town, North Gondar, Ethiopia

[11] Silverman, D. (2006), Interpreting qualitative data: Methods for analyzing talk, text, and interaction (3rd Ed). London: Sage Publications. 
Sustainable Tourism Development on Water Front Tourism and Hospitality Practices at the Tourist Destination Site: The Case of Bahirdar City, Ethiopia.

[12] Stella Kostopoulou(2013 ):On the Revitalized Waterfront: Creative Milieu for Creative Tourism department of Economics, Aristotle University of Thessaloniki, Thessaloniki 54124, Greece.

[13] UNEP (2003). Groundwater and its susceptibility to degradation: A global assessment.

Citation: Dr. Balew Baye, Dagnachew Nega. "Sustainable Tourism Development on Water Front Tourism and Hospitality Practices at the Tourist Destination Site: The Case of Bahirdar City, Ethiopia. ". International Journal of Research in Tourism and Hospitality (IJRTH), vol 6, no. 2, 2020, pp. 33-42. doi: https://doi.org/10.20431/2455-0043.0602004.

Copyright: (C) 2020 Authors. This is an open-access article distributed under the terms of the Creative Commons Attribution License, which permits unrestricted use, distribution, and reproduction in any medium, provided the original author and source are credited. 